\title{
FACTORS AFFECTING THE BRAND VALUE OF SOME PRIVATE ECONOMIC UNIVERSITIES IN HO CHI MINH CITY, VIETNAM
}

\author{
Ai Huu Tran \\ My Phan Thi Chieu \\ Dao Mai Thi Hong
}

Văn Hien University, Ho Chi Minh, Vietnam

Branding is extremely important as it has long-term implications for all organizations. Concerns about branding have been initially raised in the field of tangible products and are now shifting towards the service sector. The arguments are: (1) The intangible nature of the service makes consumers rely more on branding to support quality assessment and reduce the risk of buying decisions; (2) Many types of services need to rely on brand reputation to attract customers such as healthcare, consulting, education. Higher education is a special type of service with its own characteristics: highly intangible contents, the affects on human minds, difficulties with assessing the quality, emphasis on prestige, the need to have specific conditions to use. The above characteristics make the brand of a training/education institution become very important when future learners are making their choice.

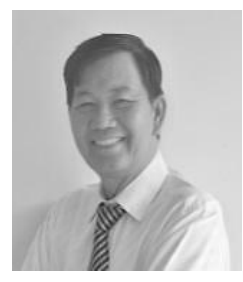

\section{Ai Tran Huu}

$\mathrm{PhD}$, Lecturer at the Economics Department, Van Hien University, Ho Chi Minh City, Vietnam.

Research interests: agricultural markets; support for small and medium enterprises; organic food market; environmental issues of economic development; multinational corporations in services' production; global competitive resources.

E-mail: aith@vhu.edu.vn

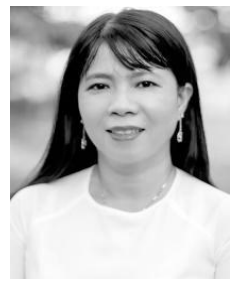

\section{Dao Mai Thi Hong}

MBA, Lecturer at the Faculty of Economics, Van Hien University, Ho Chi Minh City, Vietnam.

Research interests: consumer behavior; innovative product markets; finance.

E-mail: daomth@vhu.edu.vn

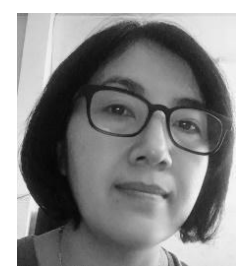

\section{My Pham Thi Chieu}

MBA, Lecturer at the Faculty of Economics, Van Hien University, Ho Chi Minh City, Vietnam.

Research interests: consumer behavior; innovative product markets; finance.

E-mail: myptc@vhu.edu.vn 
Keywords: brand value; higher education; Vietnam

\section{Introduction}

Brand value (BV) is a theoretical concept that has been interesting for researchers since the 1990s. Regarding the constituents of BV from a customer perspective, there are two main schools - those of David Allen Aaker (1991) and of Kevin Lane Keller (1993).

The Aaker school (1991) considers BV having five components or five main constituent elements which are: brand awareness, perceived quality, brand association, brand loyalty and other factors, among which brand value element is hardly mentioned in marketing research. It is intrinsically different from the original four components as it is not marketing in nature (patent, invention, goodwill, etc.).

The Keller School (1993) considers BV to be formed from consumer knowledge about brands, which consists of two main constituents - brand awareness and brand image.

Since the 1990s, studies on brand value in the world and in Vietnam have applied one of the models — Aaker (1991) or Keller (1993) — or according to the consultation approach or according to the influencing factor approach.

Brand-building is an extremely important and long-term issue for all organizations. Higher education is a special type of service with its own characteristics: highly intangible contents, various effects on human minds, difficulties while assessing the quality, strong emphasis on prestige, the necessity to have specific conditions required from the participants/learners and so on.

The above characteristics make the brand of a training institution become very important, especially when future learners are choosing an institution for themselves. Over the past 15 years, the number of higher education institutions in Vietnam has been increasing rapidly. This increase in the number of universities has made the level of competition among them much stronger. This competition can be seen between public universities; between public and non-public universities; between domestic universities and foreign universities operating in Vietnam and also between various training programs, between having work and studying at the same time, between distance learning and traditional modes of education, between the choices of second degrees, etc. The new policies of the Government and the Ministry of Education and Training in particular to improve the quality of higher education system and enhance the autonomy of universities make the branding problem even more acute. University brand has been an important highlight in marketing communications activities as it attracts learners and brings financial resources to the university.

\section{Literature review}

The American Marketing Association has defined brand equity as the value that brands bring to sellers. From the consumers' point of view, brand equity is judged based on consumer attitudes about positive brand attributes and positive results from brand usage.

Keller $(2013,41)$ stated that high brand value will bring the following benefits to sellers: (1) Awareness of product features will be more positive; (2) Higher loyalty level; (3) Less negative effects due to the marketing activities carried out by competitors; (4) Less effects due to incidents or marketing crises; (5) Higher profits overall; (6) Demand curve is less elastic when price increases; (7) Demand curve is more elastic when prices fall; (8) 


\section{FACTORS AFFECTING THE BRAND VALUE}

Better cooperation and support on the side of intermediaries; (9) There are more opportunities for licensing franchises to others; and (10) There are many brand extension opportunities.

Argenti (2000) argued that a school brand with a reputation (high brand value) brings many benefits to the school: (1) higher fees could be charged; (2) paying less to suppliers; (3) attracting best employers and trainers and (4) lower turnover rate among the staff.

Education is a specific type of service. In its turn, higher education has its own characteristics as a service. Compared to tangible products, this service has 4 specific characteristics: (1) intangibility, (2) the inseparability between production and consumption; (3) could not be warehoused; (4) heterogeneity of quality (Lovelock \& Wirtz, 2010).

Higher education belongs to the type of service that provides knowledge and/or awareness. This service is characterized by rather invisible contents and effects on the mind, spirit, attitudes, and intelligence of customers (learners). When intangible content is higher, consumers face the risk of choosing more suppliers as it gets harder to judge the actual quality. Interacting with the human mind also makes the customer/learner's assessment of the service more difficult. In that case, the role of a brand becomes even more important.

According to the ease of quality assessment, products are usually divided into three groups: search products, experience products, and prestigious products (credence products). The latter include the services in which a buyer cannot fully evaluate the quality, even when already purchased and using the product. Products in this category include training, consulting, accounting, advertising, consulting, information technology, healthcare and medical, financial services, etc.

Education and training also belong to the category of prestigious products. When choosing to purchase this type of product, buyers tend to rely on brand reputation, endorsements and guarantee from others they trust, and also service quality and price. Services of this type tend to be designed and manufactured on demand, so there usually are fewer similar products and replacements.

Therefore, it is harder for customers to compare the quality of services. Also, they are less price sensitive. Education differs from many other types of services in that not everyone wants to consume or use this type of service. Also, not all consumers can actually afford it. The reason is that in order to consume this service, the learners (service consumers) must have a certain learning capacity to pass the entrance threshold.

Besides passing this threshold, education requires learners to actively participate in the training process so that to receive knowledge, skills and attitudes in the best way and then pass periodic tests along with the final tests at the end of education. With some other types of services, the consumers just need to spend money on a service and then enjoy this service. In education and training, learners, besides paying tuition, must make efforts and spend time studying independently and participating in the training process. The more active learners are — the better would be the results.

From the employer's perspective, university's brand value is reflected in the degree to which graduates meet employers' requirements, are highly appreciated by employers and are then paid a high starting salary (Rindova et al., 2005). University branding serves as a guarantee for the applicant's knowledge, skills and the ability to work overall.

From the learner's point of view, university's brand value is the university degree that must help them minimize the risks of unemployment, get the right job having the right major, 
get a high income, be highly appreciated by employers and face good career development opportunities.

\section{The study of brand equity in the field of higher education}

Rindova et al. (2005) surveyed 1,600 businesses acting as employers of the graduates from 107 business schools in the US universities, to assess the factors that affect the organisational reputation and brand reputation of the faculty. Brand reputation is measured through prominence and perceived quality. Their research results show that brand reputation is a multidimensional concept which includes two main components: perceived quality and brand prominence, of which brand prominence is closely related to the starting salary of graduate students.

Mourad et al. (2011) studied the effects of learners' characteristics, brand awareness and brand image on university communication. The sample collected includes 135 university students and 165 high-school students preparing to enter universities in Egypt. The research results show that the majority of components in brand image have a positive impact on brand value, while the two components of brand recognition (admission promotion and word of mouth) have no significant influence on brand value.

Pinar et al. (2014) conducted an exploratory university-based study with the survey of 439 students in 30 university classes in the Midwestern region of the United States. Stemming from the model of Aaker (1991), the authors have built a scale of university communication with three old components from Aaker's model (1991): Brand awareness, perceived quality and brand loyalty. In addition, the authors added new components such as university reputation, emotions about learning environment (emotional environment), library services, student life, career development and physical facilities.

Although there have been many researches on brand value, the number of researches on brand value in the world and in Vietnam in particular is still rather small.

Especially, there hasn't been any research on the private universities' brand value and the factors influencing it in Ho Chi Minh City.

\section{Summary on the context and implications for brand equity research}

Over the past 15 years, Vietnamese higher education has undergone major changes. The number of universities has increased rapidly, the emergence of non-public universities, foreign universities in Vietnam and international joint training programs have created many learning opportunities for learners but also caused serious competitive pressure on training facilities. Among all academic major groups, the economic and business administration groups attract the largest number of Vietnamese students every year. The competition between universities in attracting students to study Economics and Business Administration is increasingly fierce. In the psychology of high-school students, college is more preferable than vocational training. In choosing a university, the school brand is the most important factor, followed by the major choice.

Facing such increased competition, university administrators are becoming increasingly aware of the importance and benefits of quality improvement and strong branding of the university. Strong brand and brand value together brings long-term competitive advantages to the domestic and international markets. The practice of branding raises in-depth research requirements about brand value, and also about the factors that have influence on brand value. 


\section{FACTORS AFFECTING THE BRAND VALUE}

Table 1 - Summary of the selected studies on university brand equity

(Source: made by the authors)

\begin{tabular}{|c|c|c|c|c|c|}
\hline Research & $\begin{array}{l}\text { Type of } \\
\text { Study }\end{array}$ & $\begin{array}{c}\text { Purpose \& Research } \\
\text { Result }\end{array}$ & $\begin{array}{l}\text { Independent } \\
\text { variables }\end{array}$ & $\begin{array}{l}\text { Dependent } \\
\text { variable }\end{array}$ & $\begin{array}{c}\text { Survey Form \& } \\
\text { Country }\end{array}$ \\
\hline $\begin{array}{c}\text { Rindova et al. } \\
\text { (2005) }\end{array}$ & $\begin{array}{l}\text { Quantitative } \\
\text { survey }\end{array}$ & $\begin{array}{l}\text { To study the influence } \\
\text { of quality factors on } \\
\text { university brand } \\
\text { reputation }\end{array}$ & $\begin{array}{l}\text { Quality of students, } \\
\text { quality of lecturers, } \\
\text { quality of facilities, } \\
\text { quality of scientific } \\
\text { research }\end{array}$ & $\begin{array}{l}\text { University } \\
\text { brand } \\
\text { reputation }\end{array}$ & $\begin{array}{c}\text { Businesses in the } \\
\text { US, acting as } \\
\text { employers }\end{array}$ \\
\hline $\begin{array}{l}\text { Mourad et } \\
\text { al. }(2011)\end{array}$ & $\begin{array}{l}\text { Quantitative } \\
\text { survey }\end{array}$ & $\begin{array}{l}\text { Building and testing } \\
\text { models affecting the } \\
\text { characteristics of } \\
\text { learners, brand } \\
\text { awareness and brand } \\
\text { image on university } \\
\text { communication values }\end{array}$ & $\begin{array}{c}\text { Learners' } \\
\text { characteristics, } \\
\text { Brand awareness, } \\
\text { Brand image }\end{array}$ & $\begin{array}{c}\text { University } \\
\text { communication } \\
\text { value }\end{array}$ & \begin{tabular}{|} 
Students studying \\
at university and \\
also those about to \\
graduate from high \\
school in Egypt
\end{tabular} \\
\hline $\begin{array}{l}\text { Pinar et al. } \\
\text { (2014) }\end{array}$ & $\begin{array}{c}\text { Quantitative } \\
\text { survey }\end{array}$ & $\begin{array}{c}\text { Building a } \\
\text { mathematical scale for } \\
\text { the concept of } \\
\text { communication in } \\
\text { universities }\end{array}$ & $\begin{array}{l}\text { Brand awareness, } \\
\text { perceived quality, } \\
\text { brand loyalty, other } \\
\text { variables }\end{array}$ & $\begin{array}{c}\text { University } \\
\text { communicatio } \\
\text { n value }\end{array}$ & $\begin{array}{l}\text { University students } \\
\text { in the US }\end{array}$ \\
\hline
\end{tabular}

Table 2 - Number and structure of universities in Vietnam, 2015 to 2019

\begin{tabular}{|l|c|c|c|c|c|}
\hline \multicolumn{1}{|c|}{ Criteria } & $2014-2015$ & $2015-2016$ & $2016-2017$ & $2017-2018$ & $2018-2019$ \\
\hline \multicolumn{1}{|c|}{ Total number of schools } & 219 & 223 & 235 & 236 & 237 \\
\hline - Public & 159 & 163 & 170 & 171 & 172 \\
\hline - Non-public & 60 & 60 & 65 & 60 & 65 \\
\hline Total number of students & $1,824,328$ & $1,753,174$ & $1,453,067$ & $1,707,025$ & $1,824,328$ \\
\cline { 1 - 5 } - Public university students & $1,596,754$ & $1,520,807$ & $1,275,608$ & $1,493,354$ & $1,596,754$ \\
\hline - Non-public university students & 227,574 & 232,367 & 177,459 & 176,669 & 227,574 \\
\hline - Full-time students & $1,348,937$ & $1,370,619$ & $1,076,233$ & $1,185,810$ & $1,348,937$ \\
\hline - Students in the learning-and-working system & 339,301 & 295,261 & 370,934 & 330,079 & 339,301 \\
\hline \multicolumn{1}{|c|}{ Divided by training levels } & \multicolumn{5}{|c|}{} \\
\hline Doctor's & 10,424 & 13,598 & 16,514 & 20,198 & 21,106 \\
\hline Master's & 37,090 & 40,426 & 43,127 & 45,266 & 44,705 \\
\hline University/college & 17,251 & 14,897 & 12,519 & 9,495 & 7,489 \\
\hline Other qualifications & 336 & 50 & 109 & 32 & 12 \\
\hline
\end{tabular}

Higher education is a specific type of service, besides, the context of higher education in Vietnam has its own, unique characteristics. Therefore, research and measurement of brand-related concepts in this field such as a brand value, brand awareness, perceived quality, brand association and brand loyalty require specific approaches. In addition to that, following international high-brand value studies, it is necessary to adjust the scale and measurement methods to suit the educational services in the Vietnamese context. 
To date, there are 223 public and private universities in Vietnam. During the last five years, the country got 49 more universities, on average, 6 new universities every year. Among these 223 universities, there are 163 public universities, accounting for nearly $3 / 5$ of their total number, while the number of non-public school accounts for more than $1 / 5$ of the total number of universities (see Tab. 4 for more details).

\section{Research models and hypotheses}

\section{Research models}

Summary on the recent domestic and international research studies on communication and other characteristics of the higher education content in Vietnam the authors of this study have borrowed from the previous studies such as those by Yoo et al. (2000), Yoo \& Donthu (2001), and Buil et al. (2013).

The factors influencing communication include the components of communication according to Aaker (1991): brand awareness, brand associations, perceived quality and brand loyalty. These variables also affect each other, according to the regression relation.

The Brand Awareness Scale is the ability of potential buyers to recall a certain brand found in a certain product category (Aaker, 1991).

The Perceived Quality scale is customers' perception of the overall quality and/or overall superiority of tangible products or services in comparison with other, similar products (Parasuraman et al., 1985, 1988).

The Brand Associations scale for university branding includes many aspects - from university reputation, majors, facilities, training programs, training organizations, tests to tuition fees, lecturers, students and so on (Pinar et al., 2014).

The Brand Loyalty scale shows the degree of buyer engagement with a brand. This loyalty includes the aspect of behavior (expressed in the frequency of repeated purchases affiliated to a particular brand) or the attitude aspect (trust, commitment, introduction to others) (Aaker, 1991).

The validity scale is a consumer's perception of the overall superior value of a product bearing in mind the brand name over other brands (Lassar et al., 1995).

\section{Research hypotheses}

H1: Brand awareness has a positive impact on the brand value of the university.

$\mathrm{H} 2$ : Perceived quality has a positive effect on the brand value of the university.

H3: Brand associations have a positive influence on the brand value of the university.

$\mathrm{H} 4$ : Brand loyalty has a positive influence on the brand value of the university.

H5: Brand awareness has a positive influence on perceived quality.

H6: Brand awareness has a positive influence on brand associations.

H7: Brand awareness has a positive influence on brand loyalty.

H8: Perceived quality has a positive impact on brand associations.

H9: Perceived quality has a positive effect on brand loyalty.

H10: Brand associations have a positive effect on brand loyalty.

Thus, we get the total of 10 research hypotheses in our research model, of which the first four hypotheses concern the impact of the four components of brand equity on the overall brand equity, while the remaining six hypotheses are related to the interaction 


\section{FACTORS AFFECTING THE BRAND VALUE}

between these four components (brand awareness, perceived quality, brand association and brand loyalty).

\section{Research methodology}

Here we are taking the research by Hair et al. (1998) for reference as to the expected sample size. Accordingly, the minimum sample size is 5 times the total number of the observed variables. This sample size is suitable for research with factor analysis application.

Thus, $\mathrm{n}=5 * \mathrm{~m} ; \mathrm{m}=44$ is the number of questions. Therefore, the number of 300 samples is acceptable for our research topic.

Surveyed sample: The people surveyed are all students who are attending private universities in Ho Chi Minh City, namely those affiliated to the Departments of Accounting, Banking and Finance, Business Administration and Economics.

The survey was conducted during October-December 2019.

The survey was conducted using the simple random sampling method with the total number of votes generated being $\mathrm{n}=585$. The response rate of the surveyed subjects is $94.34 \%$, or 552 votes. The number of questionnaires used for further analysis is $96.74 \%$, or 534 votes (88 votes were rejected due to incompleteness of answers, or when the respondents were choosing one and the same option in all the questions).

The study used the Likert scale for evaluation on a scale from 1 to 5.

The main method used for data analysis was comparative statistical method and descriptive statistics based on SPSS 23.0 software.

Further, analytical techniques such as scale reliability testing, exploratory analysis (EFA), confirmatory factor analysis (CFA) and linear structural analysis (SEM) were applied.

Among the respondents, there have been 144 students studying Business group (30.98\% of the sample), followed by the group of Finance and Banking students (166 people, or $30.07 \%$ ), then goes Economics group (119 people, or $21.56 \%$ ), and finally the group of Accounting branch (96 people, or $17.39 \%)$.

Table 3 - Survey sample divided by discipline (major)

(Source: made by the authors)

\begin{tabular}{|l|c|c|c|c|c|c|}
\hline \multicolumn{1}{|c|}{ Student groups } & $\begin{array}{c}\text { University of } \\
\text { Economics }\end{array}$ & $\begin{array}{c}\text { Bank } \\
\text { University }\end{array}$ & $\begin{array}{c}\text { Foreign } \\
\text { Trade } \\
\text { University }\end{array}$ & $\begin{array}{c}\text { University } \\
\text { of Finance }\end{array}$ & $\begin{array}{c}\text { Total } \\
\text { Ratio, } \\
\text { in } \\
\%\end{array}$ \\
\hline Business administration & 39 & 89 & 37 & 6 & 171 & 30.98 \\
\hline Accounting and Audit & 25 & 23 & - & 48 & 96 & 17.39 \\
\hline Finance and Banking & 38 & 18 & 28 & 82 & 166 & 30.07 \\
\hline Economics & 42 & 13 & 58 & 6 & 119 & 21.56 \\
\hline Total by school & 144 & 143 & 123 & 142 & 552 & 100.00 \\
\hline
\end{tabular}


Table 4 - Gender structure of the sample

(Source: made by the authors)

\begin{tabular}{|c|c|c|c|c|c|}
\hline Sample & $\begin{array}{c}\text { University of } \\
\text { Economics }\end{array}$ & $\begin{array}{c}\text { Bank } \\
\text { University }\end{array}$ & $\begin{array}{c}\text { Foreign Trade } \\
\text { University }\end{array}$ & $\begin{array}{c}\text { University of } \\
\text { Finance }\end{array}$ & Total \\
\hline Total number of students & 144 & 143 & 123 & 142 & 552 \\
\hline Overall split in \% & 26.09 & 25.91 & 22.28 & 25.72 & 100.00 \\
\hline Female students & 98 & 97 & 76 & 82 & 353 \\
\hline Female in \% & 68.06 & 67.83 & 61.79 & 57.75 & 63.95 \\
\hline Male students & 46 & 46 & 47 & 60 & 199.00 \\
\hline Male in \% & 31.94 & 32.17 & 38.21 & 42.25 & 36.05 \\
\hline
\end{tabular}

\section{Descriptive statistical analysis of the research variables}

The school's brand value is assessed through four elements which are: the ability to find suitable jobs, the ability to have high income, the ability to promote the profession and the ability to graduate from that school.

Table 5 - The importance of elements that represents the value of market brand equity (Source: made by the authors)

\begin{tabular}{|c|c|c|c|c|c|}
\hline \multirow{3}{*}{ The elements } & \multicolumn{3}{|c|}{ Evaluation of importance } & \multirow[b]{2}{*}{ Total 1} & \multirow[b]{2}{*}{ Total 2} \\
\hline & $\begin{array}{c}\text { Less } \\
\text { important }\end{array}$ & Important & $\begin{array}{c}\text { Very } \\
\text { important }\end{array}$ & & \\
\hline & A & B & $\mathrm{C}$ & $\mathrm{B}+\mathrm{C}$ & $\mathrm{A}+\mathrm{B}+\mathrm{C}$ \\
\hline The ability to find suitable jobs & 28 & 205 & 319 & 524 & 552 \\
\hline Ratio, in $\%$ & 5.07 & 37.14 & 57.79 & 94.93 & 100.00 \\
\hline The ability to have high income & 32 & 264 & 256 & 520 & 552 \\
\hline Ratio, in $\%$ & 5.80 & 47.83 & 46.38 & 94.20 & 100.00 \\
\hline Career advancement ability & 28 & 256 & 268 & 524 & 552 \\
\hline Ratio, in \% & 5.07 & 46.38 & 48.55 & 94.93 & 100.00 \\
\hline Social appreciation & 37.00 & 219 & 296 & 515 & 552 \\
\hline Ratio, in $\%$ & 6.70 & 39.67 & 53.62 & 93.29 & 100.00 \\
\hline
\end{tabular}

All four elements are highly appreciated by the society. About half of the students surveyed stated that these four items above are at the "very important" level and about 95\% think that the above elements are at the "important" and "very important" level in relation to university branding (Tab. 3).

Table 6 further shows how Vietnamese students evaluate the contribution of university communication into the elements of university brand value. 
Table 6 - Students' evaluation of university communication according to the contents of brand value

(Source: made by the authors)

\begin{tabular}{|l|c|c|c|c|}
\hline Content elements & $\begin{array}{c}\text { University of } \\
\text { Economics }\end{array}$ & $\begin{array}{c}\text { Bank } \\
\text { University }\end{array}$ & $\begin{array}{c}\text { Foreign Trade } \\
\text { University }\end{array}$ & $\begin{array}{c}\text { University } \\
\text { of Finance }\end{array}$ \\
\hline The ability to find suitable jobs & 3,55 & 3,18 & 3,28 & 3,17 \\
\hline The ability to have high income & 3,89 & 3,55 & 3,58 & 3,54 \\
\hline Career advancement ability & 4,32 & 3,90 & 4,12 & 3,92 \\
\hline Social appreciation & 4,59 & 4,35 & 4,32 & 4,36 \\
\hline Average for all four criteria & 4,09 & 3,75 & 3,82 & 3,75 \\
\hline Sample size & 144 & 143 & 123 & 142 \\
\hline
\end{tabular}

Note: Answers were obtained using the scale from 1 to 5, where 1 stands for "completely disagree" and 5 stands for "totally agree".

\section{Testing the scale of the research variables}

Cronbach Alpha test

Cronbach Alpha analysis results are based on such research concepts as Brand Awareness, Brand Associations, Perceived Quality, Brand Loyalty and Brand Value.

Exploratory factor analysis

Performing KMO and Bartlett tests with the help of SPSS 22.0 software, we have obtained the results that are showing that KMO test criteria $=0.913>0.5$ and Bartlett test criteria had a critical probability p-value (Sig.) $<0.05$. This proves that the sample is suitable for factor analysis (Hair et al., 2009, p.104).

The results of EFA analysis show that there are four factors extracted with the eigenvalue greater than 1 and the total variance extracted is 59.95\%. The scales for Brand Awareness (BAW), Perceived Quality (PQ) and Brand Loyalty (BL) all meet the unidirectional requirement.

\section{Confirmatory factor analysis}

CFA test results on the AMOS software show that this CFA model has the conformance measurement indicators of $\chi^{2} / \mathrm{df}=3.266$; $\mathrm{CFI}=0.947$; TLI $=0.933$ and RMSEA $=0.062$. According to (Hu \& Bentler, 1999) and (Hooper et al., 2008), a linear structural model that has $\chi^{2} / \mathrm{df}<5$; CFI $>0.9$; TLI $>0.9$; RMSEA $<0.08$ can be considered consistent with the actual data. In other words, the scales of the research variables Brand Awareness, Perceived Quality, Brand Associations, Brand Loyalty and brand value are all unidirectional.

\section{Testing the research hypotheses}

Test results of the standardized regression weights in the proposed linear structure model demonstrate that all of these coefficients are positive with p-value being $<0.01$ that is, statistically significant), thus showing a positive relationship between Brand Awareness, Perceived Quality, Brand association, Brand loyalty and overall brand value as hypothesized. Therefore, all the hypotheses, from $\mathrm{H} 1$ to H10, are accepted. 
Table 7 - Cronbach's Alpha coefficients of the adjusted research concept scales (Source: made by the authors)

\begin{tabular}{|c|c|c|c|c|}
\hline Item & $\begin{array}{c}\text { Scale mean if the } \\
\text { item deleted }\end{array}$ & $\begin{array}{c}\text { Scale variance if the } \\
\text { item deleted }\end{array}$ & $\begin{array}{l}\text { Corrected item } \\
\text { total correlation }\end{array}$ & $\begin{array}{c}\text { Cronbach's alpha if } \\
\text { the item deleted }\end{array}$ \\
\hline \multicolumn{5}{|c|}{ Brand Awareness $(B A W): A l p h a=0,780$} \\
\hline BAW1 & 7.26 & 1.06 & 0.547 & 0.666 \\
\hline BAW2 & 6.87 & 0.88 & 0.707 & 0.599 \\
\hline BAW3 & 6.68 & 0.85 & 0.604 & 0.616 \\
\hline \multicolumn{5}{|c|}{ Brand Associations $(B A S):$ Alpha $=0,795$} \\
\hline BAS2 & 18.80 & 6.88 & 0.449 & 0.666 \\
\hline BAS3 & 18.88 & 6.88 & 0.507 & 0.663 \\
\hline BAS4 & 18.56 & 7.08 & 0.512 & 0.662 \\
\hline BAS5 & 18.64 & 6.34 & 0.590 & 0.654 \\
\hline BAS6 & 18.83 & 6.62 & 0.546 & 0.665 \\
\hline BAS7 & 18.58 & 6.52 & 0.712 & 0.629 \\
\hline \multicolumn{5}{|c|}{ Perceived Quality $(P Q):$ Alpha $=0,804$} \\
\hline PQ2 & 8.20 & 1.10 & 0.605 & 0.666 \\
\hline PQ3 & 7.87 & 0.85 & 0.709 & 0.669 \\
\hline PQ4 & 7.63 & 0.88 & 0.641 & 0.643 \\
\hline \multicolumn{5}{|c|}{ Brand Loyalty $(B L):$ Alpha $=0,752$} \\
\hline BL2 & 14.42 & 4.63 & 0.411 & 0.646 \\
\hline BL3 & 14.76 & 4.38 & 0.607 & 0.666 \\
\hline BL4 & 14.47 & 3.88 & 0.473 & 0.636 \\
\hline BL5 & 15.10 & 4.56 & 0.545 & 0.600 \\
\hline BL6 & 14.41 & 4.51 & 0.620 & 0.666 \\
\hline \multicolumn{5}{|c|}{ Overall Brand Value $(B V):$ Alpha $=0,803$} \\
\hline BV1 & 12.13 & 2.27 & 0.599 & 0.76 \\
\hline BV2 & 11.78 & 2.10 & 0.694 & 0.71 \\
\hline BV3 & 11.36 & 2.24 & 0.672 & 0.72 \\
\hline BV4 & 11.01 & 2.52 & 0.507 & 0.70 \\
\hline
\end{tabular}

Some indicators of the model's characteristics and suitability:

$\chi 2 / \mathrm{df}=2,558 ; \mathrm{CFI}=10,969 ; \mathrm{TLI}=0,958 ; \mathrm{RMSEA}=0,052 ; \mathrm{df}=102$ Chi-Square $=$ 260,957 Chi-Square/df $=2, j \dot{j} 8 ;$-value $=0,000$ NPAR $=68$.

The research results appear to be consistent with Aaker's (1991) fundamental model of brand equity in which the author argues that the constituent factors of brand equity are Brand Awareness, Perceived Quality, Brand Association and Brand Loyalty. These are also the main sources of communication, and the constituent elements, positively (mutually) related in a rather interactive way.

\section{Recommendations on university branding}

These research results are very meaningful for brand construction and brand value management of the universities. The meanings are as follows:

1. Brand awareness is the most important factor influencing brand equity of a university. In addition, brand awareness also has a great weight as it is affecting perceived quality, brand association and brand loyalty. Therefore, it is important to focus on brand awareness as the starting point for brand equity enhancement.

2. Perceived quality is the second factor to be considered. In terms of marketing theory, 


\section{FACTORS AFFECTING THE BRAND VALUE}

quality is a solid foundation for branding in any context. According to the survey results, perceived quality has a great impact on brand value, brand association and brand loyalty.

3. Brand loyalty is the third most influential factor, straight after brand awareness and perceived quality. At the same time, brand loyalty is influenced by brand awareness, perceived quality and brand association. Therefore, in order to enhance brand loyalty, attention must be paid to building positive brand associations and programs to enhance brand loyalty.

Table 8 - Testing the research hypotheses

(Source: made by the authors)

\begin{tabular}{|l|l|c|c|c|l|c|c|}
\hline \multicolumn{2}{|c|}{ Hypothesis content } & $\begin{array}{l}\text { Standard. } \\
\text { Regression } \\
\text { Weights }\end{array}$ & $\begin{array}{l}\text { Regression } \\
\text { Weights }\end{array}$ & SE & $\begin{array}{l}\text { Critical } \\
\text { Ratio } \\
\text { (t Stat) }\end{array}$ & p-value & Decision \\
\hline $\mathrm{H}_{1}$ & $\begin{array}{l}\text { Brand awareness } \square \\
\text { Brand value }\end{array}$ & 0.429 & 0.357 & 0.053 & 6.798 & $* * *$ & Yes \\
\hline $\mathrm{H}_{2}$ & $\begin{array}{l}\text { Perceived quality } \square \\
\text { Brand value }\end{array}$ & 0.312 & 0.27 & 0.049 & 5.463 & $* * *$ & Yes \\
\hline $\mathrm{H}_{3}$ & $\begin{array}{l}\text { Brand association } \square \text { Brand } \\
\text { value }\end{array}$ & 0.127 & 0.126 & 0.039 & 3.198 & 0.001 & Yes \\
\hline $\mathrm{H}_{4}$ & $\begin{array}{l}\text { Brand loyalty } \square \\
\text { Brand value }\end{array}$ & 0.41 & 0.337 & 0.052 & 6.422 & $* * *$ & Yes \\
\hline $\mathrm{H}_{5}$ & $\begin{array}{l}\text { Brand awareness } \square \\
\text { Quality perceived }\end{array}$ & 0.714 & 0.687 & 0.053 & 12.965 & $* * *$ & Yes \\
\hline $\mathrm{H}_{6}$ & $\begin{array}{l}\text { Brand awareness } \square \\
\text { Brand association }\end{array}$ & 0.422 & 0.352 & 0.067 & 5.296 & $* * *$ & Yes \\
\hline $\mathrm{H}_{7}$ & $\begin{array}{l}\text { Brand awareness } \square \\
\text { Brand loyalty }\end{array}$ & 0.351 & 0.356 & 0.078 & 4.577 & $* * *$ & Yes \\
\hline $\mathrm{H}_{8}$ & $\begin{array}{l}\text { Quality perceived } \square \\
\text { Brand association }\end{array}$ & 0.293 & 0.255 & 0.065 & 3.906 & $* * *$ & Yes \\
\hline $\mathrm{H}_{9}$ & $\begin{array}{l}\text { Perceived quality } \square \\
\text { Brand loyalty }\end{array}$ & 0.397 & 0.419 & 0.076 & 5.544 & $* * *$ & Yes \\
\hline $\begin{array}{l}\mathrm{H} 1 \\
0\end{array}$ & $\begin{array}{l}\text { Brand association } \square \\
\text { Brand loyalty }\end{array}$ & 0.149 & 0.181 & 0.068 & 2.654 & 0.008 & Yes \\
\hline
\end{tabular}

Note: $* * *$ means p-value being <0.001. SE is standard error. CR (critical ratio) is the computed value of the Student t-test criterion about non-zero (0) of the beta coefficient (the coefficient of the regression equation).

\section{Designing a unified marketing strategy for a university}

In order to improve the university brand value, according to the main research model, it is necessary to influence brand awareness, perceived quality, brand association and brand loyalty. To positively influence those components, appropriate and effective marketing strategies and programs are needed.

Perceived quality represents consumers' perception, assessment, and perception of the overall excellence/superiority of tangible products and services, in comparison to the quality expectations about personal consumption (Parasuraman, 1985).

In the context of increasingly fierce university competition, learners' expectations for training institutions are increasing. Thus, quality improvements need to be done on a regular basis and continuously. 


\section{Building brand awareness}

A brand is only valuable when it is known by many people. Brand awareness is the beginning of the brand value creation process. Brand awareness is the design of brand identity, its application and implementation and then also external communication to create brand awareness.

\section{Limitations of the study and suggestions on further research directions}

Besides the positive contributions in theory and practice, this research also has some limitations.

In the research model, the number of research variables and observations included is quite large, the scale of some research variables in the model is not designed in detail, according to the content of each element. In fact, brand association, perceived quality and brand loyalty are complex and multi-dimensional concepts, so the use of a singledimensional scale may not accurately reflect the impact of these elements on the overall brand value. Separate studies on each component of brand equity with deeper and multidimensional scales can help to overcome this limitation.

\section{References:}

Aaker, D.A. (1991). Managing Brand Equity: Capitalizing on the Value of a Brand Name. The Free Press, New York, USA.

Aaker, D.A. (1996). Measuring Brand Equity Across Products and Markets, California Management Review, 38 (3), 102-120.

Argenti, P. (2000). Branding B-School: Reputation Management for MBA Programs, Corporate Reputation Review, 3 (2), 171-78.

Buil, I., Martinez, E. \& de Chernatony, L. (2013). The influence of brand equity on consumer responses, Journal of Consumer Marketing, 30(1), 62-74.

Hair, J.F. Jr., Black, W.C., Babin, B.J. \& Anderson, R.E. (2009). Multivariate Data Analysis, Global Perspective, $7^{\text {th }}$ edition, Pearson, New York, USA.

Keller, K.L. (1993). Conceptualizing, Measuring, Managing Customer-Based Brand Equity, Journal of Marketing, 57, 1-22.

Keller, K.L. (2013). Strategic Brand Management, $4^{\text {th }}$ edition, Pearson Education, Upper Saddle River, New Jersey, USA.

Lassar W., Mittal B. \& Sharma A. (1995). Measuring customer-based brand equity, Journal of Consumer Marketing, 12(4), 11-19.

Lovelock, C.H \& Wirtz, J. (2010). Services Marketing: People, Technology, Strategy, $7^{\text {th }}$ Edition, Prentice Hall, USA.

Mourad, M., Ennew, C., Kortam, W. (2011). Brand equity in higher education, Marketing Intelligence \& Planning, 29(4), 403-420. 


\section{FACTORS AFFECTING THE BRAND VALUE}

Parasuraman, A., Zeithaml, V.A. \& Berry, L.L. (1985). A Conceptual Model of Service Quality and Its Implications for Future Research, Journal of Marketing, Fall.

Parasuraman, A., Zeithaml, V.A.\& Berry, L.L. (1988). SERVQUAL: A Multiple- Item Scale for Measuring Consumer Perceptions of Service Quality, Journal of Retailing, 64(1), 12-40.

Pinar M., Trapp P., Girard T. and Boyt T.E. (2014). University brand equity: an empirical investigation of its dimensions, International Journal of Educational Management, 28(6), 616634.

Rindova, V.P., Williamson, I.O.\& Petkova A.P. (2005). Being good or being known: An Empirical Examination of the Dimensions, Antecedents and Consequences of Organizational Reputation, Academy of Management, 1-42.

Yoo B. \& Donthu N. (2001). Developing and validating a multidimensional consumer-based brand equity scale, Journal of Business Research, 52, 1-14.

Yoo B., Donthu N. \& Lee S. (2000). An Examination of Selected Marketing Mix Elements and Brand Equity, Journal of the Academy of Marketing Science, 28(2), 195-211.

Paper submitted

Paper accepted for publishing

Paper published online
03 August 2020

09 October 2020

30 November 2020 